\title{
Chapter 23*
}

\section{Security Challenges in Russia-European Union Relations}

\author{
Maria Raquel Freire and Licínia Simão**
}

\section{Introduction}

Russia-EU relations encompass a broad spectrum of issues across multiple levels of interaction, evidencing a mature and dense relationship between the two neighbours. Security issues remain one area where relations have encountered greater challenges, reflecting an evolving understanding of security matters, as well as the distinct nature of both actors. In this chapter, we advance a broad understanding of security as necessary to address the many aspects that the EU and Russia have defined as relevant in their perceptions of and interactions with each other. Although many of these security dimensions are not new, as they were already developed in the context of the Helsinki Process in the 1970s, they acquire new relevance depending on the interactions between both actors and the broader regional and international context. We argue therefore that there is no linearity in the assessment of Russia-EU security relations. On the one hand, we can see both cooperative and uncooperative behaviours coexisting in the same period of time across different issues. On the other hand, within one same issue we can also see evolving patterns of relations across time. This suggests that Russia-EU security relations, particularly in the wider European context, remain largely dependent on domestic factors, including the

\footnotetext{
* Freire, Maria Raquel; Simão, Licínia (2019), Security Challenges in Russia-European Union Relations, in Roger E. Kanet (org.), Routledge Handbook of Russian Security. Oxon and New York: Routledge.

** This research was supported by Funding from the European Union under the MSCA European Training Network CASPIAN, grant no. 642709.
} 
specificities of decision-making of each actor, as well as on external factors, particularly regional dynamics in the post-Soviet space and great Middle East, and relations with the United States (US). This chapter addresses EU member states policies only when relevant to understand EU policy making.

The chapter starts with a mapping exercise, identifying the many issues covered by the spectrum of security relations between the EU and Russia. It addresses the main academic views on the topic, including those from different theoretical traditions, as well as the priorities established by the two actors. This literature varies considerably in its assessment of the elements structuring these relations, as well as of the achievements reached. Authors addressing energy security, for instance might underline how both actors have managed to develop a system where mutually beneficial relations were established, despite the difficulties being experienced since the gas crisis of 2006 in Ukraine. However, authors dealing with security in the shared neighbourhood have put forward a dismay picture of uncooperative behaviour and competition, which has resulted in an unprecedented level of insecurity since the Cold War. Nuclear issues have also been an area where both the EU and Russia have cooperated, in order to bring about denuclearization both regionally in Europe and globally, as the joint efforts in the Iranian nuclear deal illustrate. They have, nevertheless, sponsored opposing views of the elements needed to assure societal security in their respective societies. This complex picture seems to suggest that different understandings have been favoured at different points in time, depending on a series of factors.

The chapter then engages more directly with the ways in which issues have been placed on the bilateral EU-Russia security agenda, and how the different policy documents and options have addressed these varying priorities. We identify major tensions in the bilateral security agenda, including divisions over the US global interventionist policies following 9/11, suspicion over the 
colour revolutions in the post-Soviet space, the North Atlantic Treaty Organization (NATO) enlargement policy, Kosovo, and Russia’s military intervention in Georgia and in Ukraine among others. Many of these issues evidence the strong impact that the regional and global context bears on these relations. Finally, the chapter discusses future challenges regarding cooperative and uncooperative trends in Russia-EU security relations, including issues on cyber security, hybrid warfare and popular mobilisation, in a context of tensions over Ukraine and uncertainty at home.

\section{Mapping the field: security issues in EU-Russia relations}

Security remains one of the most complex and contested concepts in International Relations, especially due to the continuous enlarging of its scope and meaning. Security no longer relates exclusively to national (state) security and has come to include other referent objects (individuals, communities, multinational corporations, the environment). It is no longer assured mainly by military means, since the threats to security have grown more complex, as have the number of issues considered relevant for security (Buzan, Wæver, de Wilde, 1997). EU-Russia security relations are not an exception to this evolving field of study. An analysis of the historical development of Russia's and EU's security policies evidences largely distinct starting points and frameworks of reference, but also a trend towards approximation and complexification of each actor's security policies.

For the EU developing a common security policy has been a complex process, due to the unique features of its supranational integration. Peace and security through functional cooperation and dialogue have resulted in important security gains for EU member states and for countries in the EU's neighbouring regions, namely those dealing with conflicts and which have been granted membership perspectives (Diez, Stetter and Albert, 2006; Bremberg, 2015). The EU has thus 
advanced a normative conception of regional security based on the principles enshrined in EU founding treaties, including liberal democracy, human rights, the rule of law and market economies. The EU's late development of integrated mechanisms to manage military capabilities and increased spending in defence cooperation through Permanent Structured Cooperation (PESCO), followed this historically-placed emphasis of its security policies on normative and economic means. The promotion of a norms-based international order constitutes the European Union's main contribution to European security (Manners, 2002; Tèlo, 2011).

Russia’s security approach in the 1990s was very much focused on internal threats arising from 'economic decline, instability and societal problems' (Lomagin, 2016, 127; see also Military Doctrine, 1993; National Security Concept, 1997), and external challenges to Russian security were to be addressed in "'partnership" with the West', allowing a focus on non-military security (ibid). The Russian Federation's territorial integrity as well as the ability of the state structures to safeguard national institutions, including economic and financial ones, were major concerns (Clark and Graham, 1995; Stepanov, 2000). A further issue that was rather prominent during the 1990s was management (or rather the mismanagement) of the military arsenal of the former Soviet Union, including its nuclear facilities (Booth, 1992; Graham, 1996). Nuclear security was also on the agenda well into the early 2000s regarding non-proliferation issues and Russia's important role in this regard, as well as the potential links between nuclear weapons and terrorism (Bunn, 2005). For most of this period, the EU was not a privileged interlocutor with Moscow for military issues, but rather the US and leading European powers, like France and the United Kingdom. The EU became increasingly relevant in financial and economic issues, especially as the 1990s advanced and a new Partnership and Cooperation Agreement between the two partners came into force in 1997. 
The 2000s brought a change in Russia's political leadership with Vladimir Putin coming to power and developments in Russia's relations with the West that prompted a revision of Moscow's security policy. The wars in Yugoslavia and NATO's intervention in 1999, the ongoing Chechen wars, lack of agreement with the West on offensive and defensive weapons, the Iraq war and later projects such as the US defence missile shield and the antagonising issue of NATO enlargement, all set the stage for the development of a more independent and self-assuring security policy that would reflect Russia's status as a great power, accompanied by the means to face domestic and external threats. The focus on the internal-external security nexus has remained central in Russian security policy, and non-traditional security issues have featured on the agenda despite Moscow's traditional national security concerns very much focused on preserving its sovereignty, and its focus on military means as a source of power projection, as seen in Georgia (2008), and more recently Ukraine (2014) and Syria (2015) (Freire and Heller, 2018; Mearsheimer, 2014). In this context, discussions on the level of Russia and the EU partnership became prominent (Timmins, 2002), namely due to their divergent identities and self/mutual perceptions (Ispa-Landa, 2003; Diez, 2004). The inability to renegotiate a new framework agreement with the EU since 2007 and the consequences of the war in Ukraine (2014 to present), including the imposition of sanctions, have rendered discussion on security matters between these two parties even more complex, particularly regarding the so-called third common space, of external security. ${ }^{1}$

\footnotetext{
${ }^{1}$ EU-Russia relations have been structured on the existing PCA as well as on the 2003 agenda on the development of four common spaces: a common economic space, a common space of freedom, security and justice, a common space of co-operation in the field of external security, and common space on research, education and culture.
} 
In this setting a major issue in the literature dealing with EU-Russia security relations has been the impact of the EU's enlargement and neighbourhood policies on Russia's regional strategic interests and its self-perception as a regional and global power (Freire, 2018a; O’Brennan, 2006; Averre, 2005; Light and White, 2000). The overlapping neighbourhood has grown into an area of high intensity confrontation between the two actors, as evidenced in Georgia (2003 and 2008) and Ukraine (2004 and 2014). The critical geopolitical readings of the shared space between Russia and the EU and the distinctive narratives constructed demonstrate how relevant the overlapping neighbourhood is in EU-Russia security relations. The heterogeneity and agency that is recognised to the states in the common neighbourhood of the EU and Russia, along with the interplay of perceptions (including ontological security approaches), have been identified as most relevant to understand and interpret EU-Russia security relations in their neighbourhood (Browning, 2018; Svarin, 2016; Smith, 2016; Rieker and Gjerde, 2016; Pop, 2016; Dias, 2013; Simão, 2011).

Energy security also gradually made its way onto the common EU-Russia agenda, especially as a reflection of the important political role ascribed to energy development in Vladimir Putin's foreign policy. However, the different contexts in the EU and Russia where energy policies have been developing paved the way for difficulties in finding agreement over a common energy policy (Locatelli, 2013; Talseth, 2017). Some authors even argue that in the process the EU revealed incapable of defining a unified policy and speaking at one voice in energy-related matters (Kuzemko, 2014). This meant that only with a regulatory framework reflecting all stakeholders' interests and a fair distribution of risks it would be possible to assure predictability in energy relations between these actors (Kaveshnikov, 2010; Van Der Meulen, 2009). The energy crises involving Ukraine in 2006 and 2009 disrupted gas supplies from Russia to the EU transiting through Ukraine due to lack of agreement on the new prices for gas supplies from Russia to 
Ukraine. Authors addressing these issues underlined the risks associated to Moscow's political use of energy, as a tool for leverage over the post-Soviet countries (Helén, 2010), with Nygren (2008) defining the policy's two main strategies as the 'tap weapon' and the 'transit weapon'. The negative impacts on Russia's credibility as an energy supplier to the EU were immediately visible, leading the Union to look for diversification strategies. These same dynamics became present in Russia's policy of diversification. Moreover, asymmetrical interdependence would highlight the fragility of one of the parties whereas conferring added leverage to the other (Krickovic, 2015), leading to the need to redefine policy goals. Nevertheless, Milatschew (2012) makes the case that in its relations with the EU, Russia's power only affects cooperation between these two actors in a marginal way, contrary to what is often argued. In this same critical line, Lukáš Tichý and Petr Kratochvíl (2014) add that the narratives implied in energy security integration, liberalisation and diversification show a more complex picture than the usual cooperation/confrontation binary analysis (see also Casier, 2016).

The normative dimensions of security have also remained an important element in analyses of EU-Russia relations (Sakwa, 2017; Haukkala, 2010). The contestation to the liberal regimes in Western Europe, which is increasingly visible in Russia (Romanova, 2018; Freire, 2018b; Jankovski, 2017), but also inside the European countries with the rise of radical political parties, has been addressed as a potential security issue on the common agenda. If democracy and free market economies are a central part of the Union's self-perceived role in stabilising Europe, the undermining of these principles, namely since the financial crisis of 2008, pose significant challenges to the EU's central role in providing for European security. Derek Averre (2016) claims that a security governance framework helps in explaining how EU-Russia relations have developed, particularly considering Russia's revisionism of the western order and criticism of its 
institutional arrangements, which has had a clear impact on readings about security in the wider Europe, with the case of Ukraine illustrating this dynamic process.

Russia has also increasingly perceived the importance of addressing the normative and soft dimensions of power, articulating an alternative vision to Western leadership, based on multipolarity and conservative values. Although initially multipolarity included the EU as an alternative pole of power to the US, several authors have highlighted the disappointment in Moscow regarding the inability of the EU to balance US global interventionist policies and to defend principles of international law (Makarychev and Morozov, 2011; Tsygankov, 2011). Despite a similar normative rhetoric, the meanings attributed by the two actors to norms and their role in providing for security varies considerably. According to some authors, this has prevented the development of a multilateral setting for security issues (Fernandes, 2011). The definition of Russia in the European security architecture as 'an object of security', as argued by Diesen (2017a) contributes to exacerbate a collision trajectory based on a zero-sum game. According to the author, this is linked to the development of the EU and NATO as 'inter-democratic security institutions', which Russia has been reading as following an antagonistic path. The issue of NATO enlargement has been in the agenda for a long time, with Russia understanding the further extension of the Atlantic Alliance as a major external threat to its security. In this context, Russia has been pursuing a selective approach in its relations with the EU that became both cooperative and competitive in its nature (Kropatcheva, 2012). The images of national identity, honour, international power and global role, although shared by both authors as important elements, articulate largely different images of international politics and its development (Tsygankov, 2014; Nitoiu, 2017; Diesen, 2017b). 


\section{Security challenges to EU-Russia relations in a regional and global setting}

The European 'security architecture' has evolved around the central role of NATO, the marginal role of the Organization for Security and Cooperation in Europe (OSCE) and a limited contribution from the EU. In the process the NATO-Russia Council was established in 2002 (replacing the 1997 Permanent Joint Council), but Russia never considered itself fully integrated in the European security system (de Haas, 2010; Kortunov, 2016; Lavrov, 2018). Moreover, the structural policies of regional integration, namely NATO and EU enlargements and the development of the EU Neighbourhood Policy have, nevertheless, remained largely disarticulated from EU discourse on security. 'Civilian power Europe' (Bull, 1982; Stavridis, 2001; Tèlo, 2006) only recently engaged with the challenges of thinking and developing its security policies, namely with the establishment of a Common Foreign and Security Policy (CFSP) and a European Security and Defence Policy (ESDP). Also, the adoption of the European Security Strategy (ESS) of 2003 (Council of the European Union, 2003) contributed to clarifying the perceived threats and priority fields, but did not articulate a clear definition of what EU security is or should be. In the absence of a consensus in this regard, different conceptions of security emerged both from the various institutional actors and among EU member states, combining structural approaches and crisis and conflict management tools (Freire and Simão, 2018).

The role of Russia in these emerging EU security policies was surprisingly marginal, at least until 2008. The ESS refers to Russia's role in four areas, including energy security, managing the stabilisation of the Western Balkans, of the Israeli-Arab conflict, as well as the importance of developing a strategic partnership with Moscow that 'Respect[s] [...] common values' (Council of the European Union, 2003, p. 14). The conflicts in the shared neighbourhood with Russia are marginally referred in the 2003 document, but emerge as a central concern in the 2008 Report on 
the Implementation of the European Security Strategy (Council of the European Union, 2008), in view of the deterioration of relations with Russia following the 2008 Russian-Georgian war. Similarly, the 2016 Global Strategy of the EU raises the concerns of the Union vis-à-vis Russia, explicitly identifying Moscow as one of the biggest security concerns for the EU and its member states, and stating that 'Russia's violation of international law and the destabilisation of Ukraine, on top of protracted conflicts in the wider Black Sea region, have challenged the European security order at its core' (European Commission and High Representative of the EU for Foreign Affairs and Security Policy, 2016, 33). Relations with Russia have remained largely strained since the annexation of Crimea, in 2014, both at high political level and intermediate ones. Tatiana Romanova (2016) addresses the negative impacts of the imposition of Crimea-related sanctions by the EU, underlining how relations have been negatively affected, even at the more horizontal technical level. In the aftermath of difficult relations with Russia, in March 2016 the EU put forward the five principles for guiding relations with Russia, which reflect this difficult security atmosphere. These principles include: full implementation of the Minsk agreements; closer ties with Russia's former Soviet neighbours; strengthening EU resilience to Russian threats; selective engagement with Russia on certain issues such as counter-terrorism; and support for people-topeople contacts (Russell, 2016). The principles sum up what are different security understandings in the EU and Russia, with Moscow voicing criticism of EU conditions.

This analysis evidences how Russia is simultaneously a security concern for the EU and other European actors and is a security actor in its own terms. Moscow's policies have reflected this dual status and have incorporated the effects of these external perceptions. Russia's conceptualisation of security has maintained a strong focus on military issues and national security, gradually incorporating other strategic dimensions, including energy, food, and environmental 
security, among others. The linkages between the rights of citizens, sustainable economic development and the traditional values of 'sovereignty, independence, state and territorial integrity' have been recurrent in official Russian security documents (see RNSS, 2015, §6). The identification of diversified threats to Russia's security leads to a listing of military and nonmilitary measures to respond to current challenges, while also clearly linking internal development in different spheres (economic, cultural, social) to external security, by addressing issues such as corruption or ideological use of systems of communication and information, among other (RNSS 2015, § 43; Freire and Simão, 2018).

Russia's own views regarding the ordering of European security and its place in it have thus been a central element in its security policies, as mentioned. The feeling of encirclement, mainly driven by NATO enlargement and reinforced by the EU's Neighbourhood Policy, has been a central element sustaining the drive towards a new military build-up and an arms race, both by EU-NATO countries and Russia. In fact, Russia has advanced alternative visions for the reordering of European security. Both in its 1999 Medium Term Strategy for Development of Relations with the European Union, and later with the European Security Treaty Proposal advanced by thenpresident Dmitry Medvedev in 2008 (The Kremlin, 2009; RFE/RL, 2009), Russia underlined the importance of keeping the principles of cooperative security as drafted back in 1975, while recognizing the limits of the OSCE and of the need to bring forward something new. 'Overall, the proposal meant to refurbish old principles and bring Russia back into the European security discussion and decision-making' (Freire and Simão, 2018).

There are valid reasons for Russia to be invested in the materialization of a new more inclusive European security regime, where Russia would have voice, vote and veto, and which would be based on shared principles of sovereignty and respect for the territorial integrity of states, 
as core norms binding the parties into the common framework proposed. However, difficulties remain in finding a balance between the current contested order and new proposals to reshape it. The Ukraine conflict and the annexation of Crimea questioned the very foundations of the security regime Russia has been promoting, given the violation of the very basic principles that were at the core of this security order. The end-result has not only been the imposition of sanctions, but also contradictory dynamics regarding Russia's inclusion in the European security system. It is a formal part of this architecture, but it is not a member of the institutions that have come to dominate the management of European security, namely NATO and the EU. The annexation of Crimea and the crisis in Ukraine represent a definitive shift with regard to Russia's position in the European security order, distancing Moscow from agreed norms and shared principles, including on border regimes. Regionalism, in the shape of traditional spheres of influence, seems to be back and it is informing the erosion of the European security regime.

Since the Ukrainian crisis began in 2013, the management of security relations between the EU, including its member states, and Russia has sharply deteriorated. This crisis also illustrates rather well how EU-Russia security relations are exposed to regional and global dynamics. US policies towards Russia and European security more broadly have been major factors, shaping the approximation of both actors (as was partly the case with the US decision to invade Iraq in 2003) (Gordon and Shapiro, 2004), or further setting them apart, as was the case with Kosovo's unilateral declaration of independence, in 2008 (Antonenko, 2017). US policies of global intervention, which became particularly active after 9/11, have been at the heart of Russian criticisms, as famously voiced by President Putin in Munich in 2007 (Putin, 2007). Calls for the EU to distance itself from these policies have only marginally led to a more fruitful dialogue between Moscow and Brussels. Regional dynamics further impact on this relation, as illustrated by the management of the Iranian 
nuclear programme. Russia has remained a crucial element on this issue, both as a supplier of nuclear technology to Iran and as a critical element in the negotiations (Omelicheva, 2012). In fact, as the Trump administration decided to withdraw from the Nuclear deal with Iran and restate the sanctions regime, Russia-EU relations have found new ground on which to improve (Viscusi and Meyer, 2018; Thomson and Kulesa, 2017. Despite the positive alignment of interests on Iran, EURussia relations remain divergent regarding the Astana process over Syria, which is managed by Russia, Turkey and Iran, without EU or US participation, and remain divergent regarding the implementation of the Minsk Agreements over Ukraine.

\section{Looking ahead: EU-Russia security challenges}

Delinking the regional dimension of security in EU-Russia relations from the more global context where relations take place is difficult. In fact, the regional challenges relate to the narratives associated to the 'shared' neighbourhood which have become increasingly antagonistic, or to counter-terrorism activities, which have provided ground for closer collaboration, mingle with the role of other players and spaces such as the US, Turkey or even China. This means that the internalexternal nexus applies both to security readings within the EU and Russia and to those regarding their relationship. Challenges at the structural level will remain with the redefinition of the European security order providing ground for competitive and cooperative relations. Transnational threats to security coming from criminal organisations, cyber-security threats or terrorist groups, with a transnational dimension, will keep adding to the security challenges these players face. At the actor's level, overcoming the mistrust, even in face of a military build-up scenario and hostile discourse, and reaching the political conditions for the normalization of relations will remain on the agenda. These points to the fact that the security challenges ahead might bring in new 
dimensions, but in essence they are not new. The way cyber-security, propaganda and fake news, and new-armaments' development have made it to EU-Russia relations poses new challenges not so much in their novelty, but more regarding the need for sophisticated answers that these technological changes require, as visible for example in the creation by Russia and the EU of active responsive bodies to propaganda.

The ways forward are, however, not bright. An attempt to reinstate the old status quo through a 'reset-type' exercise would be insufficient in face of the inadequacy of this very old order that revealed to be limited. 'Moscow's answer to the EU's mantra, [that] "there is no return to the business as usual for Russia" is: we do not want business as usual' (Romanova, 2016). A deeper reassessment needs, therefore, to be made. Starting anew might mean the need for the joint definition of policies and actions, and joint monitoring of results - i.e. co-ownership of decisions (Casier, et al., 2016) and processes. The recognition that security and integration mean different things to Russia and the West must be at the basis of the identification of the structural causes that need to be tackled. Ad hoc and small-scale initiatives might ease tensions, but they will not solve crystalized differentials. For these, confidence-building measures and constructive dialogue need to be built from scratch. Moreover, engaging 'constructively with geopolitics through gradual and selective economic cooperation with the Eurasian Economic Union and by preparing the way for a robust diplomatic process on European security with Russia' (Koenig, 2016, 1) might prove useful in overcoming opposing narratives, policies and actions whereas providing ground for the sharing of security approaches in EU-Russia relations.

A major challenge to these potentially positive steps remain the domestic dynamics both within the EU and its member states and in Russia. The incorporation of domestic dynamics into the analysis is fundamental, in order to account for intra-EU pressures for greater military 
investment, which have been largely legitimised as a response to a perceived revisionist-Russian stance (Nielsen, 2017). Moreover, pressures on the EU's democratic institutions and the election of extremist parties have been interlinked with accusations of Russian interference in domestic political processes, raising tension over a new field of perceived insecurity in EU-Russia relations (Dobrokhotov, 2017). The ways in which the Russian regime will manage the pressures associated with the economic and political impact of the existing sanctions regime and the future of Russia after Putin remain important challenges to EU-Russia security relations. Overcoming mistrust and addressing the important issues on the common security agenda will require a reassessment of Russia's current role as a major threat to EU member states, as well as a new assessment in Moscow of the role of the former Soviet space in its regional and global affirmation strategies.

\section{References}

Antonenko, Oksana (2007) 'Russia and the Deadlock over Kosovo', Survival, Vol.49, no.3, pp. 91-106.

Averre, Derek (2016) 'The Ukraine Conflict: Russia's Challenge to European Security Governance', Europe-Asia Studies, Vol.68, no.4, pp. 699-725.

Averre, Derek (2005) 'Russia and the European Union: Convergence or Divergence?', European Security, Vol.14, no.2, pp. 175-202.

Booth, Ken (1992) 'Loose Nukes and the Nuclear Mirror: The Dangers and Opportunities Resulting from the Breakup of the Soviet Union', Arms Control, Vol.13, no.1, pp. 140150. 
Bremberg, Niklas (2015) 'The European Union as Security Community-Building Institution: Venues, Networks and Co-operative Security Practices', Journal of Common Market Studies, Vol.53, no.3, pp. 674-692.

Browning, Christopher S. (2018) 'Geostrategies, geopolitics and ontological security in the Eastern neighbourhood: The European Union and the "new Cold War", Political Geography, Vol.62, no.1, pp. 106-115.

Bull, Hedley (1982) 'Civilian Power Europe: A Contradiction in Terms?', Journal of Common Market Studies, Vol.21, no.2, pp. 149-170.

Bunn, Matthew (2005) 'Preventing a Nuclear 9/11', Issues in Science \& Technology, Vol.21, no.2, pp. 55-62.

Buzan, Barry (1983) People, States \& Fear: An Agenda for International Security Studies in the Post-Cold War Era. Brighton: Wheatsheaf.

Casier, Tom (2016) 'Great Game or Great Confusion: The Geopolitical Understanding of EURussia Energy Relations', Geopolitics, Vol.21, no.4, pp. 763-778.

Casier, Tom et al. (2016) 'Policy Report. EU-Russia Relations: Which Way Forward?', Jean Monnet Multilateral Research Group, EU-Russia Relations: Developing a Transnational Perspective. Available at https://www.kent.ac.uk/brussels/studying/research/projects/jeanmonnet.html (accessed 20 May 2018).

Clark, Susan L and Graham, David R. (1995) 'The Russian Federation's fight for survival', Orbis, Vol.39, no.3, pp. 329-352.

De Haas, Marcel (2010) 'Medvedev's alternative European security architecture', Security and Human Rights, Vol.21, no.1, pp. 45-48. 
Dias, Vanda Amaro (2013) 'Perspectives on European Politics and Society’, Vol.14, no.2, pp. 256271.

Diesen, Glenn (2017a) EU and NATO Relations with Russia: After the Collapse of the Soviet Union. London: Routledge.

Diesen, Glenn (2017b) 'The EU, Russia and the Manichean Trap', Cambridge Review of International Affairs, Vol.30, no.2-3, pp. 177-194.

Diez, Thomas (2004) 'Europe's others and the return of geopolitics', Cambridge Review of International Affairs, Vol.17, no.2, pp. 319-335.

Dobrokhotov, Roman (2017) 'Is Russia a real threat to the West?', Aljazeera, 31 July. Available at https://www.aljazeera.com/indepth/opinion/2017/07/russia-sanctions-united-states170729121726556.html (accessed 20 May 2018).

Fernandes, Sandra (2011) 'European Security through EU-Russian Relations: Towards a New Multilateral Order'? Journal of Contemporary European Research, Vol.7, no.2, pp. 195215.

Freire, Maria Raquel (2018a) 'The quest for status: how the interplay of power, ideas, and regime security shapes Russia's policy in the post-Soviet space', International Politics, https://doi.org/10.1057/s41311-018-0164-y.

Freire, Maria Raquel (2018b) 'Political Dynamics within the BRICS in the Context of Multilayered Global Governance'. In John Kirton and Marina Larionova (ed.), BRICS and Global Governance. London: Routledge.

Freire, Maria Raquel and Heller, Regina (2018) 'Russian power politics in Ukraine and Syria: status-seeking between identity, opportunity and costs', Europe-Asia Studies (forthcoming). 
Freire, Maria Raquel and Simão, Licínia (2018) 'EU-Russia Relations and the Unravelling of the European Security Regime in the Context of the Ukraine Crisis'. In Tom Casier and Joan DeBardeleben (ed.), EU-Russia Relations in Crisis. Understanding Divergent Perspectives. London: Routledge.

Gordon, Philip H. and Shapiro, Jeremy (2004) Allies at War: America, Europe, and the Crisis Over Iraq. New York: McGraw-Hill.

Haukkala, Hiski (2016) The EU-Russia Strategic Partnership. The Limits of Post-Sovereignty in International Relations. London: Routledge.

Helén, Henry (2010) 'The EU’s energy security dilemma with Russia', POLIS Journal, Vol.4. Available at http://www.polis.leeds.ac.uk/assets/files/students/student-journal/ma-winter10/helen-e.pdf (accessed 20 May 2018).

Ispa-Landa, Simone (2003) 'Russian Preferred Self-Image and the Two Chechen Wars', Demokratizatsiya, Vol.11, no.2, pp. 305-319.

Jankovski, Aleksandar (2017) 'The Russian Federation and the West: The Problem of International Order'. In Roger E. Kanet (ed.) The Russian Challenge to the European Security Environment. Cham, Switzerland: Palgrave Macmillan.

Kaveshnikov, Nikolay (2010) 'The issue of energy security in relations between Russia and the European Union', European Security, Vol.19, no.4, pp. 585-605.

Koenig, Nicole (2016) 'Taking the ENP beyond the Conception-Performance Gap', Jacques Delors Institut Policy Paper no.160, 22 March.

Kortunov, Andrey (2016) 'How not to talk with Russia', 1 April. Available at https://www.ecfr.eu/article/commentary_how_not_to_talk_with_russia_6053 (accessed 20 May 2018). 
Krickovic, Andrej (2015) 'When Interdependence Produces Conflict: EU-Russia Energy Relations as a Security Dilemma', Contemporary Security Policy, Vol.36, no.1, pp. 3-26.

Kropatcheva, Elena (2012) 'Russian foreign policy in the realm of European security through the lens of neoclassical realism', Journal of Eurasian Studies, Vol.3, no.1, pp. 30-40.

Kuzemko, Caroline (2014) 'Ideas, power and change: explaining EU-Russia energy relations', Journal of European Public Policy, Vol.21, no.1, pp. 58-75.

Lavrov, Sergei (2018) 'Russia's Foreign Policy in a Historical Perspective', Russia in Global Affairs, 20 March. Available at http://eng.globalaffairs.ru/number/Russias-Foreign-Policyin-a-Historical-Perspective-19445 (accessed 20 May 2018).

Light, Margot; White, Stephen; and Löwenhardt, John (2000) 'A wider Europe: The view from Moscow and Kyiv', International Affairs, Vol.76, no.1, pp. 77-88.

Locatelli, Catherine (2013) 'Les enjeux de sécurité dans la relation gazière UE-Russie', Revue d'économie industrielle, Vol.3, no.143, pp. 35-69.

Lomagin, Nikita A. (2016) 'Russia's CIS Policy and Economic and Political Transformations in Eurasia'. In Roger E. Kanet and Rémi Piet (ed.), Shifting Priorities in Russia's Foreign and Security Policy. Oxon: Routledge.

Makarychev, Andrey and Morozov, Viatcheslav (2011) 'Multilateralism, Multipolarity, and Beyond: A Menu of Russia’s Policy Strategies', Global Governance, Vol.17, no.3, pp. 353-373.

Manners, Ian (2002) 'Normative Power Europe: A Contradiction in Terms?', Journal of Common Market Studies, Vol.40, no.2, pp. 235-258.

Mearsheimer, John J. (2014) 'Why the Ukraine Crisis Is the West's Fault. The Liberal Delusions That Provoked Putin', Foreign Affairs, September/October. Available at 
https://www.foreignaffairs.com/articles/russia-fsu/2014-08-18/why-ukraine-crisis-west-sfault (accessed 20 May 2018).

Milatschew, Valentina (2012) EU-Russian energy relations: How Russia's power affects its willingness to cooperate with the European Union in gas-related matters. Saarbrücken: Lambert Academic Publishing.

Military Doctrine (1993) 'The Basic Provisions of the Military Doctrine of the Russian Federation'. Available at https://fas.org/nuke/guide/russia/doctrine/russia-mil-doc.html (accessed 20 May 2018).

National Security Concept (1997) 'Concept of National Security of the Russian Federation'. Approved by Presidential Decree of 17 December 1997, no. 1300. Available at https://www.prlib.ru/en/node/354146 (accessed 20 May 2018).

Nielsen, Nikolaj (2017) 'Russia threat triggers European military spending hike', EUObserver, Brussels, 24 April. Available at https://euobserver.com/foreign/137645 (accessed 20 May 2018).

Nitoiu, Cristian (2017) 'Aspirations to Great Power Status: Russia's Path to Assertiveness in the International Arena under Putin', Political Studies Review, Vol.15, no.1, pp. 39-48.

Nygren, Bertil (2008) The Rebuilding of Greater Russia: Putin's Foreign Policy towards the CIS Countries. London: Routledge.

O’Brennan, John (2006) “Bringing Geopolitics Back In”: Exploring the Security Dimension of the 2004 Eastern Enlargement of the European Union', Cambridge Review of International Affairs, Vol.19, no.1, pp. 155-169.

Omelicheva, Mariya Y. (2012) 'Russia's Foreign Policy toward Iran: A Critical Geopolitics Perspective', Journal of Balkan \& Near Eastern Studies, Vol.14, no.3, pp. 331-344. 
Pop, Adrian (2016) 'From cooperation to confrontation: the impact of bilateral perceptions and interactions on the EU-Russia relations in the context of shared neighbourhood', Eastern Journal of European Studies, Vol.7, no.2, pp. 47-70.

Putin, Vladimir (2007) 'Speech and the Following Discussion at the Munich Conference on Security Policy', February 10, Munich. Available at: http://archive.kremlin.ru/eng/speeches/2007/02/10/0138_type82912type82914type82917t ype84779_118123.shtml (accessed 20 May 2018).

Rieker, Pernille and Gjerde, Kristian Lundby (2016) 'The EU, Russia and the potential for dialogue - different readings of the crisis in Ukraine', European Security, Vol.25, no.3, pp. 304325.

Romanova, Tatiana (2018) 'Russia's Neorevisionist Challenge to the Liberal International Order', International Spectator, Vol.53, no.1, pp. 76-91.

Romanova, Tatiana (2016) 'Russia and Europe: Somewhat Different, Somewhat the Same?', Russian International Affairs Council Policy Brief no.5. Available at http://russiancouncil.ru/common/upload/Russia-Europe-Policybrief5-en.pdf (accessed 20 May 2018).

RNSS (2015) 'Russian National Security Strategy, December 2015 [Text of 31 December Russian Federation Presidential Edict 683 approving appended text of 'The Russian Federation's $\begin{array}{llll}\text { National Security } & \text { Strategy']'. } & \text { Available at }\end{array}$ www.ieee.es/Galerias/fichero/OtrasPublicaciones/Internacional/2016/Russian-NationalSecurity-Strategy-31Dec2015.pdf (accessed 20 May 2018).

Russell, Martin (2016) ‘The EU’s Russia Policy. Five Guiding Principles', European Parliament Research Service (EORS) Briefing, PE 589.857, October. 
Sakwa, Richard (2017) Russia Against the Rest: The Post-Cold War Crisis of World Order. Cambridge: Cambridge University Press.

Simão, Licínia (2011) 'Discursive differences and policy outcomes: EU-Russia relations and security in Europe', Eastern Journal of European Studies, Vol.2, no.1, pp. 81-95.

Smith, Nicholas Ross (2016) EU-Russian Relations and the Ukraine Crisis. Cheltenham: Edward Elgar Publishing.

Stavridis, Stelios (2001) “"Militarising” the EU: The concept of civilian power Europe revisited', The International Spectator, Vol.36, no.4, pp. 43-50.

Stepanov, Valery (2000) 'Ethnic tensions and separatism in Russia', Journal of Ethnic \& Migration Studies, Vol.26, no.2, pp. 305-332.

Svarin, David (2016) "The construction of "geopolitical spaces" in Russian foreign policy discourse before and after the Ukraine crisis', Journal of Eurasian Studies, Vol.7, pp. 129140.

Talseth, Lars-Christian U. (2017) The Politics of Power: EU-Russia Energy Relations in the $21^{\text {st }}$ Century. Cham, Switzerland: Palgrave Macmillan.

Telò, Mario (2011) 'The European Union, regionalism, and world order: five scenarios', Fédéralisme Régionalisme, Vol.11, no.2. Available at https://popups.uliege.be/13743864/index.php?id=1090\&format=print $($ accessed 20 May 2018).

Telò, Mario (2006) Europe: A Civilian Power? European Union, Global Governance, World Order. Basingstoke: Palgrave Macmillan.

Tichý, Lukáš and Kratochvíl, Petr (2014) 'The EU-Russia Energy Relations under the Prism of the Political Discourse', Perspectives, Vol.22, no.1, pp. 5-32. 
Timmins, Graham (2002) 'Strategic or pragmatic Partnership? The European Union's Policy Towards Russia Since the End of the Cold War', European Security, Vol.11, no.4, pp. 7895.

Thomson, Adam and Kulesa, Lukasz (2017) 'Support for the Iran Nuclear Deal Brings the EU and Russia Closer Together', European Leadership Network Commentary, 14 November. Available at https://www.europeanleadershipnetwork.org/commentary/support-for-theiran-nuclear-deal-brings-the-eu-and-russia-closer-together/ (accessed 20 May 2018).

Tsygankov, Andrei P. (2014) 'The frustrating partnership: Honor, status, and emotions in Russia's discourses of the West', Communist and Post-Communist Studies, Vol.47, no.3-4 pp. 345354.

Tsygankov, Andrei P. (2011) 'The Russia-NATO mistrust: Ethnophobia and the double expansion to contain “the Russian Bear"”, Communist and Post-Communist Studies, Vol.46, no.1, pp. 179-188.

Van Der Meulen, Evert Faber (2009) 'Gas Supply and EU-Russia Relations’, Europe-Asia Studies, Vol.61, no.5, pp. 833-856.

Viscusi, Gregory and Meyer, Henry (2018) 'Macron Heads to Russia in European Effort to Salvage Iran Deal', Bloomberg, 22 May. Available at https://www.bloomberg.com/news/articles/2018-05-22/macron-heads-to-russia-ineuropean-effort-to-salvage-iran-deal (accessed 22 May 2018). 